\title{
Malignant transformation in mature cystic teratoma of the ovary: a retrospective study of eight cases and review of literature
}

\author{
Ruchi Rathore ${ }^{1,2}$, Sonal Sharma ${ }^{1}$, Sarla Agarwal ${ }^{1}$ \\ ${ }^{1}$ University College of Medical Sciences, New Delhi, India \\ ${ }^{2}$ North Delhi Municipal Corporation Medical College and Hindu Rao Hospital, New Delhi, India
}

\begin{abstract}
Introduction: Mature cystic teratoma (MCT) is the most common type of ovarian germ cell neoplasm, but occasionally it may undergo malignant change in any one of its elements. In this study, these rarely encountered tumors, occurring over a period of 25 years, were studied.

Material and methods: A retrospective, tertiary hospital-based study was carried out in all histopathologically diagnosed cases of MCT (230) of the ovary from January 1990 to December 2014. The clinicopathological features of malignant transformation (MT) in MCT of the ovary were retrieved from the archives of the Department of Pathology and were analyzed.

Results: Two hundred thirty (230) mature cystic teratomas of the ovary were found. MT was noted in eight of these cases, i.e. $3.5 \%$ of all the MCT. The mean age of the patients with MCT was $32.5 \pm 13.11$ while the mean age of the patients with malignant transformation in MCT was $44.2 \pm 8.94$ years. Grossly the mean size of the malignant teratoma was $11.7 \pm 2.7 \mathrm{~cm}$, whereas it was $7.6 \pm 2.1 \mathrm{~cm}$ for mature cystic teratoma. Squamous cell carcinoma (SCC) was the most frequent MT seen in four out of eight cases, while one case showed an adenocarcinoma and the other a malignant melanoma, and two cases had transitional cell carcinoma.

Conclusions: The rate of malignant transformation in MCT increases with age and is much higher in the postmenopausal age group. Moreover, although SCC is still the commonest, transitional cell carcinoma (TCC) may also develop not infrequently as malignancy apart from other rare differentiations such as adenocarcinoma or malignant melanoma in an MCT.
\end{abstract}

Key words: ovarian tumor, teratoma, malignant transformation, squamous cell carcinoma, transitional cell carcinoma, malignant melanoma.

\section{Introduction}

Mature cystic teratoma (MCT) of the ovary, commonly known as dermoid cyst, has been known since antiquity. MCT is the most common type of ovarian germ cell neoplasm. It occurs relatively frequently and comprises approximately $20 \%$ of all ovarian neoplasms [1, 2]. In its pure form, mature cystic teratoma is always benign. Malignant transformation (MT) is an uncommon complication of a mature cystic teratoma. It occurs in approximately $1-3 \%$ of all MCT cases, although in one report the frequency was as high as 6.67\% [3-5].

The lack of specific signs and symptoms indicating a malignant transformation, their similarity to MCT and their uncommon occurrence makes it difficult to diagnose such transformations pre-operatively [5]. Hence, MT arising in an MCT is currently diagnosed by postoperative pathological examination in most cases. In this study, these rarely encountered tumors, occurring over a period of 25 years were further studied.

\section{Material and methods}

A retrospective study was carried out in all histopathologically diagnosed cases of MCT (230) of the ovary from January 1990 to December 2014. Relevant data were retrieved from the archives of the Department of Pathology. Institutional Ethics committee approval was obtained before retrieving the data for this retrospective study. Eight cases of a malignant tumor arising in a teratoma were identified. The mean age and size of the tumors were noted in all the patients with MT in MCT and compared with those of MCT. The morphological and clinicopathological features of MT in MCT of the ovary were analyzed. Chi square test, using SPSS software version 22, was performed to find the association of age, size and laterality of these tumors with MT. 


\section{Results}

A total of 1102 ovarian tumors were diagnosed over a period of 25 years. $25.7 \%$ (284/1102) of all the ovarian tumors were germ cell tumors. Of the consecutive 242 cases of ovarian teratoma 231 (20.9\%) were MCT and $11 / 242$ cases of immature teratoma. For statistical purposes we took 230 cases of MCT in this study. Malignant transformation was noted in eight of these cases, i.e. $3.5 \%(8 / 230)$ of all the MCT.

Whereas the mean age of the patients with MCT was $32.5 \pm 13.11$ years, ranging from 8 years to 70 years, the mean age of the patients with malignant transformation in MCT was $44.2 \pm 8.94$ (mean \pm standard deviation) years, ranging from 33 years to 56 years. Considering the fact that MCT are a rare occurrence in the postmenopausal age group, in our study 19/223 cases, i.e. $8.2 \%$ of all the MCT, were seen in postmenopausal females, and 4 of these 19 cases had developed malignant transformation. The association of age of the patients and malignancy status was found to be statistically significant ( $p$ value $=0.035$ ), indicating that the chances of a tumor being malignant were higher as the age increased. The most common symptom of presentation was painful abdomen (5/8) followed by lump in the abdomen (Table 1).

Duration of symptoms ranged from 3 to 6 months except in one patient, who presented with a short history of 3 days as acute pain of the abdomen due to torsion. Owing to the lack of specific symptoms suggestive of a malignant transformation in a teratoma, these cases are often missed. In this study only one case of adenocarcinoma with metastasis, presenting with ascites and pleural effusion, was clinically suspected to have malignancy. Considering the laterality of this transformation, it was found that while 4 cases were right sided the other 4 were left sided. The association of laterality with malignancy was not found to be statistically significant $(p=0.241)$.

In all the cases where radiological investigations were available, it was found that although malignancy was suspected in $25 \%$ (2/8) of cases none of the cases were diagnosed as MT in these investigations. One of the cases was diagnosed as mature cystic teratoma on contrast enhancing computed tomography (CECT)

Table 1. Clinicopathological features of all eight cases of malignant transformation arising in mature cystic teratoma

\begin{tabular}{|c|c|c|c|c|c|c|c|}
\hline No. & $\begin{array}{c}\text { Age } \\
\text { (years) }\end{array}$ & Laterality & Symptoms & Investigations & Tumor gross & $\begin{array}{l}\text { Clinical } \\
\text { diagnosis }\end{array}$ & $\begin{array}{c}\text { Histopathological } \\
\text { diagnosis }\end{array}$ \\
\hline 1 & 35 & Left & Pain $\times 6$ months & $\begin{array}{l}\text { USG: cystic } \\
\text { mass with few } \\
\text { solid areas }\end{array}$ & $\begin{array}{c}\text { Solid cystic ovarian } \\
\text { mass } \\
12 \times 8.5 \times 6 \mathrm{~cm} \\
\text { C/s variegated }\end{array}$ & $\begin{array}{l}\text { Dermoid } \\
\text { cyst ovary }\end{array}$ & SCC in teratoma \\
\hline 2 & 42 & Left & $\begin{array}{l}\text { Lump } \times 5 \text { months } \\
\text { Pain } \times 3 \text { months }\end{array}$ & $\begin{array}{l}\text { CECT: mature } \\
\text { cystic } \\
\text { teratoma left } \\
\text { ovary }\end{array}$ & $\begin{array}{l}15 \mathrm{~cm} \text { diameter } \\
\text { predominantly } \\
\text { cystic mass with } \\
\text { tiny solid areas }\end{array}$ & $\begin{array}{c}\text { Malignant } \\
\text { ovarian tumor }\end{array}$ & SCC in teratoma \\
\hline 3 & 56 & Right & $\begin{array}{c}\text { Pain } \times 4 \text { months } \\
\text { Post-menopausal } \\
\text { bleeding } \times 3 \text { months }\end{array}$ & $\begin{array}{c}\text { USG: cystic } \\
\text { ovarian mass } \\
\text { with few solid } \\
\text { areas }\end{array}$ & $\begin{array}{l}14 \times 10 \times 3.5 \mathrm{~cm} \\
\text { solid cystic mass }\end{array}$ & $\begin{array}{l}\text { Malignant } \\
\text { tumor ovary }\end{array}$ & $\begin{array}{l}\text { Teratoma } \\
\text { with TCC }\end{array}$ \\
\hline 4 & 50 & Right & Pain $\times 6$ months & $\begin{array}{l}\text { USG: possibly } \\
\text { malignant } \\
\text { ovarian tumor }\end{array}$ & $\begin{array}{c}12 \times 7 \times 5 \mathrm{~cm} \\
\text { bosselated solid } \\
\text { cystic ovarian mass }\end{array}$ & $\begin{array}{c}\text { Malignant } \\
\text { ovarian tumor }\end{array}$ & $\begin{array}{l}\text { Teratoma with } \\
\text { malignant } \\
\text { melanoma }\end{array}$ \\
\hline 5 & 55 & Right & Lump $\times 4$ months & $\begin{array}{c}\text { USG: solid } \\
\text { cystic ovarian } \\
\text { mass }\end{array}$ & $\begin{array}{c}10 \times 7 \times 6 \mathrm{~cm} \text { well- } \\
\text { circumscribed solid } \\
\text { cystic with areas } \\
\text { of hemorrhage and } \\
\text { necrosis }\end{array}$ & $\begin{array}{l}\text { Dermoid? } \\
\text { Malignancy? }\end{array}$ & $\begin{array}{l}\text { Teratoma with } \\
\text { grade III TCC }\end{array}$ \\
\hline 6 & 33 & Left & Lump $\times 4$ months & NA & $\begin{array}{l}12 \mathrm{~cm} \text { diameter } \\
\text { cystic mass with } \\
\text { one polypoidal } \\
\text { solid area }\end{array}$ & Dermoid cyst & SCC in teratoma \\
\hline 7 & 37 & Left & Acute pain $\times 3$ days & NA & $\begin{array}{l}13 \times 10 \times 7 \mathrm{~cm} \text { solid } \\
\text { cystic ovarian mass }\end{array}$ & $\begin{array}{l}\text { Solid cystic } \\
\text { ovarian mass? } \\
\text { Dermoid? }\end{array}$ & SCC in teratoma \\
\hline 8 & 46 & Right & $\begin{array}{l}\text { Abdominal distention } \\
\times 1 \text { month, ascites } \\
\text { and pleural effusion }\end{array}$ & $\begin{array}{l}\text { USG: ovarian } \\
\text { malignancy }\end{array}$ & $\begin{array}{c}6 \mathrm{~cm} \text { diameter } \\
\text { predominantly } \\
\text { solid mass with } \\
\text { hair and pultaceous } \\
\text { material inside }\end{array}$ & $\begin{array}{c}\text { Malignant } \\
\text { ovarian tumor }\end{array}$ & $\begin{array}{c}\text { SCC } \\
\text { Adenocarcinoma } \\
\text { in teratoma } \\
\text { metastatic } \\
\text { to omentum }\end{array}$ \\
\hline
\end{tabular}

NA - not available, SCC - squamous cell carcinoma, TCC - transitional cell carcinoma 

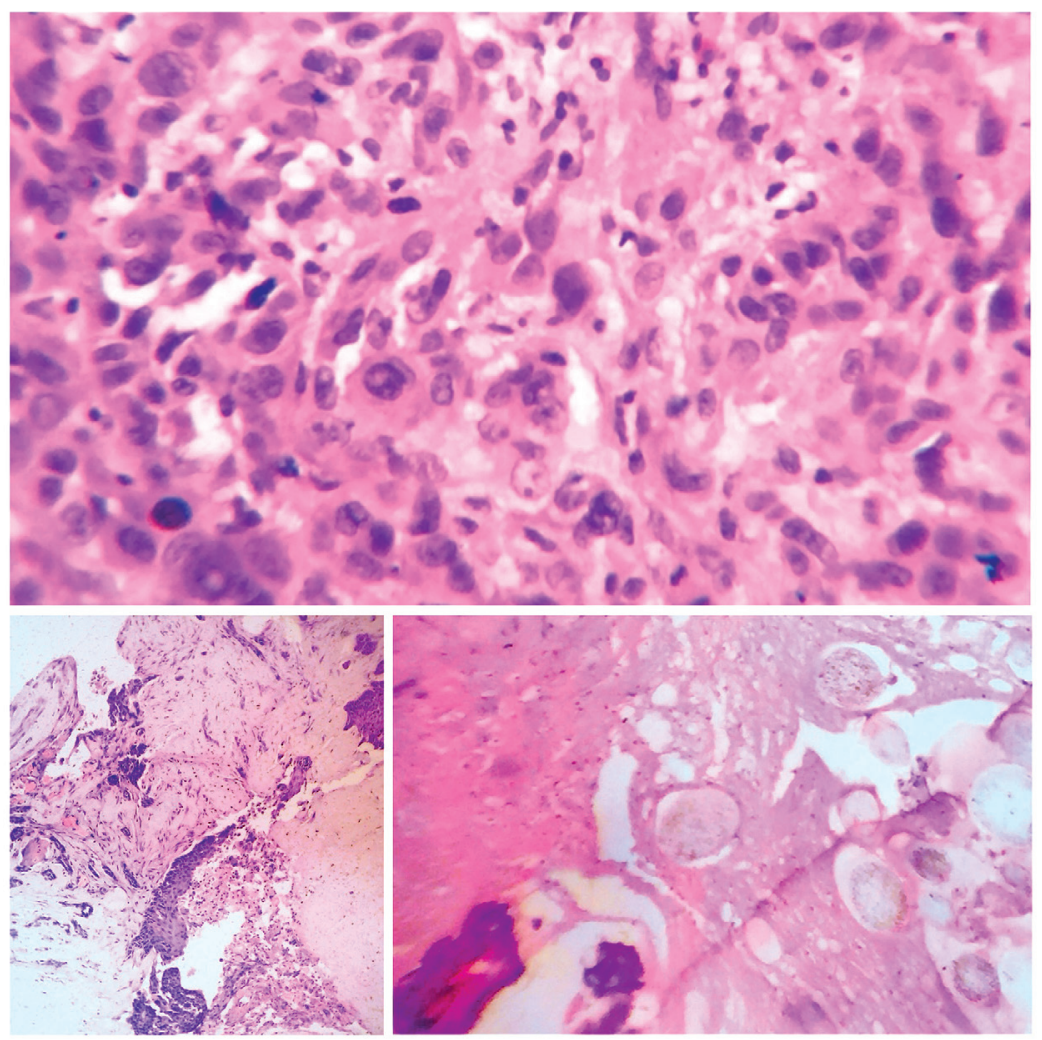

Fig. 1. Areas with malignant transformation into squamous cell carcinoma, nests of malignant squamous cells infiltrating the stroma with entrapped hair follicles $(H \& E \times 40)$

of the abdomen but turned out to be a squamous cell carcinoma developing in a mature cystic teratoma on histopathology sections. Clinical and radiological details of patients and histopathological diagnosis are summarized in Table 1.

\section{Pothological findings}

\section{Gross examination}

Grossly the mean size of MT in MCT was $11.7 \pm 2.7 \mathrm{~cm}$, whereas it was $7.6 \pm 2.1 \mathrm{~cm}$ for mature cystic teratoma. The cut surface for all MT in MCT was predominantly solid cystic with only two of eight cases having a variegated appearance. The tumors were predominantly cystic, filled with pultaceous material and hair. Foci of solid areas were identified in all the cases. In one case, the tumor had undergone partial necrosis and hemorrhage, presumably due to torsion. The association of size of the tumor with malignancy status was found to be statistically significant $(p=0.00)$ in this study.

\section{Microscopic examination}

All the tumors showed keratinized stratified squamous epithelium, hair follicles, sebaceous glands, lobules of mature cartilage, glands lined by respiratory mucosa, skeletal muscle and adipocytes. Digestive tract mucosa was also identified in one case. No immature elements were identified in any of the cases. Squamous

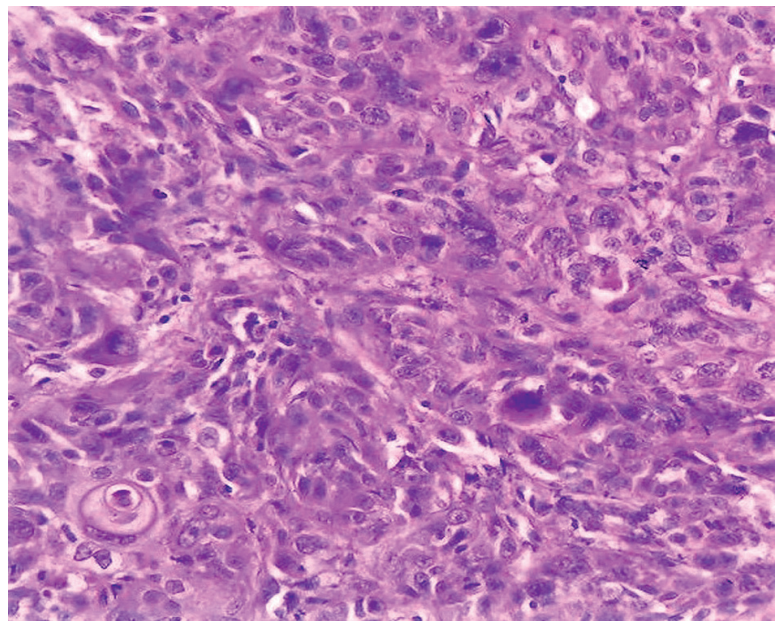

Fig. 2. Squamous cell carcinoma with atypical mitotic figures $(H \& E \times 400)$

cell carcinoma (SCC) was the most frequent MT (Figs. 1 and 2), seen in four out of eight cases (50\%), while one case showed an adenocarcinoma and the other a malignant melanoma, and two cases $(25 \%)$ had malignant transformation in the form of transitional cell carcinoma (Figs. 3-5). The only case where the suspicion of malignancy was high and the patient presented with ascites had adenocarcinoma in the peritoneum (Fig. 3). While $5 / 8$ cases were treated with a total abdominal hysterectomy with bilateral salpingo-oophorectomy, in 




Fig. 3. Adenocarcinoma with glands and numerous mitotic figures (arrows) $(H \& E \times 40)$



Fig. 4. Malignant melanoma arising in mature cystic teratoma showing sheets of epithelioid cells with vesicular nuclei, prominent eosinophilic nucleoli and melanin $(H \& E \times 400)$

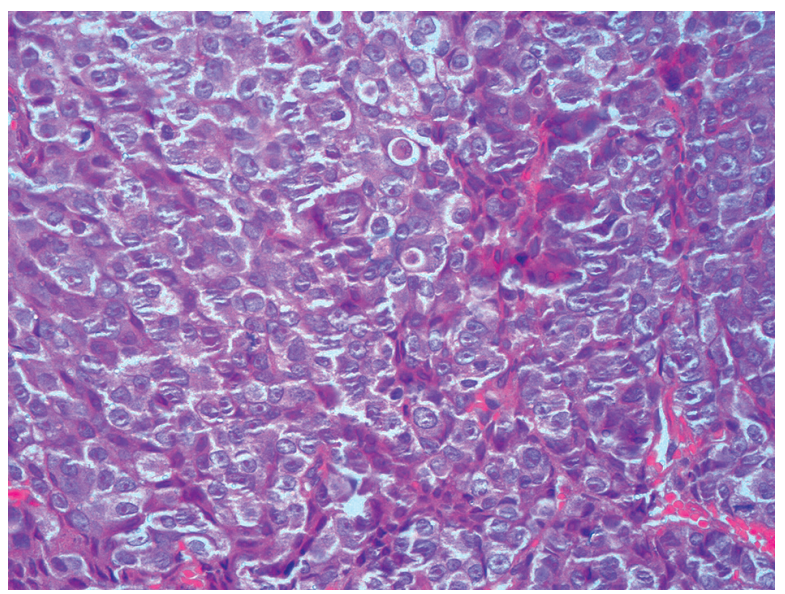

Fig. 5. Transitional cell carcinoma arising in mature cystic teratoma $(H \& E \times 400)$

3/8 cases unilateral salpingo-oophorectomy was performed. A peritoneal biopsy was also taken along with the removal of tumor in one case where the suspicion of metastasis was high.

\section{Discussion}

Malignant transformation of a mature cystic teratoma is exceedingly rare and occurs in only $1-3 \%$ of cases $[3,5]$. However, there are two studies where the frequency of such malignant transformation was as high as $6.67 \%$ and $5 \%$ respectively $[4,6]$. The frequency in our study is higher than the reported literature, at 3.5\%.

Kikkawa et al. studied 37 cases of SCC arising from MCT in a 17-year period [7]. In their study the mean age of patients with SCC of the ovary was 55.2 years as against 37.5 years in patients with MCT. The mean age of patients with MT in our series was however slightly earlier, being 44 years as against 32.5 years for MCT. The rarity of this malignant transformation is generally true for all age groups, but the chances of any of the components becoming malignant is higher in perimenopausal and older women, as is seen in this study. Described uncommonly in postmenopausal women, we had $8.2 \%(19 / 230)$ cases of MCT, of which $21 \%(4 / 19)$ had MT, i.e. of all the 8 cases of MT $50 \%$ (4/8) belonged to the postmenopausal age group (45-55 years). Wei et al. analyzed mature cystic teratomas in postmenopausal women and found that $7.6 \%$ of the total number of patients with benign ovarian teratomas had MT [8]. The incidence of malignant change in the postmenopausal age group in their study was $15 \%$ as against $21 \%$ in this study. The mean size of a malignant ovarian dermoid as studied by Kikkawa et al. Was $15.2 \mathrm{~cm}$, compared to 8.8 $\mathrm{cm}$ in benign dermoid tumor [7]. However, in our study the mean sizes of both MCT and MCT with MT were smaller, being $7.6 \mathrm{~cm}$ for MCT and $11.7 \mathrm{~cm}$ for MT.

MT arising from MCT is diagnosed with difficulty in the preoperative period. Quite often, although the patients present with a painful abdomen or a lump in the abdomen, the possibility of MT in MCT is still missed owing to the lack of any specific signs and symptoms. Moreover, the preoperative radiological findings also in these patients may not differ much from those seen in uncomplicated MCT. Only a high index of suspicion based on history and examination of the patient may give a clue towards the diagnosis. Patients with MT of MCTs may sometimes present with a rapidly enlarging tumor or may present with systemic symptoms suggestive of malignancy in an advanced stage of the disease, as seen in one of our cases with a positive peritoneal biopsy. Most of our patients presented with abdominal pain and a history of lump in the abdomen, except one where the presentation was acute due to torsion of the tumor. The radiological investigations suspected a malignancy in only $2 / 8$ cases. The diagnosis of MT in MCT was suspected in none of the cases radiologically.

The role of serum markers such as SCC antigen is also questionable in such cases since MT in MCT is a very rare occurrence, and is often not suspected on radiological or clinical examination. Mori et al. found 
Table 2. Comparison of our study with other studies

\begin{tabular}{|c|c|c|c|c|c|c|c|c|c|}
\hline $\begin{array}{l}\text { Study } \\
\text { No. }\end{array}$ & Author (year) & $\begin{array}{l}\text { Duration of } \\
\text { study (years) }\end{array}$ & $\begin{array}{l}\text { Percen- } \\
\text { tage }\end{array}$ & MT & $\begin{array}{l}\text { Mean age } \\
\text { (years) }\end{array}$ & $\begin{array}{c}\text { Mean } \\
\text { size }(\mathrm{cm})\end{array}$ & $\mathrm{CL} / \mathrm{F}$ & $\begin{array}{c}\text { Types } \\
\text { of carcinoma }\end{array}$ & $\begin{array}{l}\text { Most } \\
\text { common }\end{array}$ \\
\hline 1 & Ulker et al. (2012) [3] & 9 & 1.9 & 6 & 43 & 11.5 & Pain & $\begin{array}{l}\mathrm{SCC}, \mathrm{Cd} \\
\text { M Aca }\end{array}$ & SCC \\
\hline 2 & Harshmohan et al. (2007) [4] & 6 & 6.67 & 5 & 46 & 11.6 & Pain & SCC, PTC & SCC \\
\hline 3 & Rim et al. (2006) [13] & 20 & 1.7 & 11 & 50.6 & NA & Lump & SCC, Aca & SCC \\
\hline 4 & Present study & 25 & 3.5 & 8 & 44 & 11.7 & Pain & $\begin{array}{l}\text { SCC, TCC, } \\
\text { MM, Aca }\end{array}$ & SCC \\
\hline 5 & $\begin{array}{l}\text { Sakuma et al. } \\
\text { (2010) [18] }\end{array}$ & 18 & NA & 37 & 52.5 & 8.8 & NA & $\begin{array}{l}\text { SCC, Aca, } \\
\text { ASca, MM }\end{array}$ & \\
\hline 6 & Araujo et al. (2015) [19] & 5 & 5.5 & 10 & 36 & NA & NA & $\begin{array}{c}\text { SCC, PTC } \\
\text { ASca, } \\
\text { Aca, WD NE } \\
\text { Ca }\end{array}$ & SCC \\
\hline 7 & $\begin{array}{l}\text { Oranratanaphan et al. } \\
\qquad(2013)[20]\end{array}$ & 10 & 1.46 & 11 & 41.2 & 14.1 & Lump & $\begin{array}{c}\text { SCC, M Aca } \\
\text { Aca }\end{array}$ & $\begin{array}{l}\mathrm{SCC}=\mathrm{M} \\
\mathrm{Aca}\end{array}$ \\
\hline 8 & Fu Fan et al. (2013) [21] & 48 & 8 & 3 & 48 & 16 & NA & SCC & SCC \\
\hline 9 & Futagami et al. (2012) [22] & 7 & 2.6 & 2 & 42.5 & 10 & Lump & SCC & SCC \\
\hline 10 & Black et al. (2015) [23] & 8 & 1.2 & 7 & 53.7 & 18 & $\begin{array}{l}\text { Bloating, } \\
\text { pain }\end{array}$ & $\begin{array}{l}\text { M Aca, MM, } \\
\text { SCC, PD Aca }\end{array}$ & M Aca \\
\hline
\end{tabular}

MT - malignant transformation, CL/F - clinical features, NA - not available, SCC - squamous cell carcinoma, Cd - carcinoid, M Aca - mucinous adenocarcinoma, Aca - adenocarcinoma, PTC - papillary thyroid carcinoma, ASca - adenosquamous carcinoma, WD NE Ca - well-differentiated neuroendocrine carcinoma

that a combination of patient's age (above 40 years) with serum SCC antigen level (> $2.5 \mathrm{ng} / \mathrm{ml}$ ) may be considered as a suitable marker for diagnosis [9]. Some studies including those of Suzuki et al. [10] and Mayazaki et al. [11] concluded that SCC antigen alone or in combination with other markers, such as macrophagecolony stimulating factor (M-CSF) and carcino-embryonic antigen (CEA), may be considered as suitable markers for a preoperative diagnosis of MT in MCT. But since the serum level of SCC antigen depends on the tumor volume, early detection of small tumors becomes difficult. However, in the present study serum SCC levels were not determined in any of the cases, possibly due to the lack of a strong clinical and radiological suspicion of a malignant change and the poor economic status of the patients.

All the tumors in our study showed keratinized stratified squamous epithelium, hair follicles, sebaceous glands, lobules of mature cartilage, glands lined by respiratory mucosa, skeletal muscle and adipocytes, but no immature elements were identified in any of these cases. Mature thyroid tissue along with other derivatives was seen in one of the cases. Struma ovarii was seen in 6/230 cases and neural differentiation was seen in $3 / 230$ cases. $11 / 230(5.2 \%)$ cases of immature teratoma were identified in the study over a period of 25 years, but none of these had evidence of MT as is found in MCT.

The most common MT reported in the literature is SCC, as is also seen in the present study [3]. Hirakawa et al. studied the clinical and pathological features of 28 patients with SCC arising in MCT of the ovary [12]. In 11 tumors, SCC was considered to have originated from a columnar epithelium (ciliated or non-ciliated) or from a metaplastic squamous epithelium. But in none of the cases was SCC a direct transition from the ordinary epidermis of the teratomatous skin tissue. However, in the present series, although the carcinoma arising from keratinized squamous epithelium was documented in one out of the four cases, the origin from columnar or metaplastic epithelium was seen in none. The comparison of our study with other studies on MT is shown in Table 2.

The pathogenesis of MT in MCT is still not clear. Rim et al. [13] studied 11 cases of MT in MCT and hypothesized that since $80 \%$ of MCTs are diagnosed during reproductive age, MT may develop due to the long-term presence of non-removed MCT. Though the reason for this is not clear, it is postulated by some authors that the long-term presence of mature cystic ovarian teratoma and squamous metaplasia of the columnar epithelium may be followed by such malignant change. Molecular studies conducted so far on these cases do show some evidence of p53 overexpression as a causative factor [14].

Though the most common malignancy seen in an MCT is SCC, which represents about $75 \%$ of malignant transformation, other neoplasms, including adenocarcinoma, neuroectodermal tumors, sarcoma, and malignant melanoma, have also been reported [15-21]. In 
our study also SCC was the most frequently identified malignant transformation, found in four out of eight cases (50\%). There was one case of adenocarcinoma and malignant melanoma each. The fact that although SCC was still the commonest tumor to be found, two cases of transitional cell carcinoma (TCC) (25\%) were found in our study is unlike any other study reported so far. Malignant melanoma arising within a mature cystic teratoma is also extremely rare, with an estimated incidence of 0.2 to $0.8 \%$ [16]. In our study, out of the 230 cases of MCT, we had only one case of malignant melanoma, giving an incidence of $0.4 \%$.

SCC arising in MCT of the ovary have been associated with a very poor prognosis in various studies [17]. Age, tumor size, clinical stage, histologic differentiation, capsular invasion and the presence of vascular invasion may predict the survival of patients with SCC arising from MCT [7, 12]. Unlike other tumors of the ovary, SCC of the ovary spreads transmurally with extensive local invasion. Hirakawa et al. reported an overall 5-year survival rate of $52 \%$ in their series of 28 patients [12]. Since ours was a retrospective study, a comment on prognosis cannot be made due to the unfortunate lack of complete follow-up of these patients.

\section{Conclusions}

We conclude that although rare, the rate of malignant transformation in MCT increases with age and is much higher in the postmenopausal age group, as compared to younger women, possibly due to the longer duration of MCT found in these women. A higher index of suspicion must be maintained for MCT occurring in the postmenopausal age group. Moreover, although SCC is still the commonest, TCC may also develop not infrequently as malignancy apart from other rare differentiations such as adenocarcinoma or malignant melanoma in an MCT.

\section{Disclosure}

The authors report no conflict of interest.

\section{References}

1. Peterson WF, Prevost EC, Edmunds FT, et al. Benign cystic teratomas of the ovary; a clinic-statistical study of 1007 cases with review of the literature. Am J Obstet Gynecol 1955; 70: 368-382.

2. Roth LM, Talerman A. Recent advances in the pathology and classification of ovarian germ cell tumors. Int J Gynecol Pathol 2006; 25: 305-320.

3. Ulker V, Numanoglu C, Akbayir O, et al. Malignant transformation arising from mature cystic teratoma of the ovary: A report of six cases. J Obstet Gynaecol Res 2012; 38: 849-853.

4. Bal A, Mohan H, Singh SB, et al. Malignant transformation in mature cystic teratoma of the ovary: report of five cases and review of the literature. Arch Gynecol Obstet 2007; 275: 179-182.

5. Curling ON, Potsides PN, Hudson CN. Malignant change in benign cystic teratoma of ovary. Br J Obstet Gynecol 1979; 86: 399-402.
6. Papadias K, Kairi-Vassilatou E, Kontogiani-Katsaros K, et al. Teratomas of the ovary: a clinico-pathological evaluation of 87 patients from one institution during a 10-year period. Eur J Gynaecol Oncol 2005; 26: 446-448.

7. Kikkawa F, Nawa A, Tamakoshi K, et al. Diagnosis of squamous cell carcinoma arising from mature cystic teratoma of ovary. Cancer 1998; 82: 2249-2255.

8. Wei F, Jiang Z, Yan C. Analysis of 20 mature ovarian cystic teratoma cases in postmenopausal women. Chin Med J (Engl) 2001; 114: 137-138.

9. Mori Y, Nishii H, Takabe K, et al. Preoperative diagnosis of malignant transformation arising from mature cystic teratoma of the ovary. Gynecol Oncol 2003; 90: 338-341.

10. Suzuki M, Tamura N, Kobayashi H, et al. Clinical significance of combined use of macrophage colony-stimulating factor and squamous cell carcinoma antigen as a selective diagnostic marker for squamous cell carcinoma arising in mature cystic teratoma of the ovary. Gynecol Oncol 2000; 77: 405-409.

11. Miyazaki K, Tokunaga T, Katabuchi H, et al. Clinical usefulness of serum squamous cell carcinoma antigen for early detection of squamous cell carcinoma arising in mature cystic teratoma of the ovary. Obstet Gynecol 1991; 78: 562-566.

12. Hirakawa T, Tsuneyoshi M, Enjoji M. Squamous cell carcinoma arising in mature cystic teratoma of the ovary. Clinicopathologic and topographic analysis. Am J Surg Pathol 1989; 13: 397-405.

13. Rim SY, Kim SM, Choi HS. Malignant transformation of ovarian mature cystic teratoma. Int J Gynecol Cancer 2006; 16: 140-144.

14. Yoshioka T, Tanak T. Immunohistochemical and molecular studies on malignant transformation in mature cystic teratoma of the ovary. J Obstet Gynaecol Res 1998; 24: 83-90.

15. Ueda G, Fujita M, Ogawa $\mathrm{H}$, et al. Adenocarcinoma in a benign cystic teratoma of the ovary: Report of a case with a long survival period. Gynecol Oncol 1993; 48: 259-263.

16. Dasgupta T, Brasfield R. Metastatic melanoma. A clinicopathological study. Cancer 1964; 17: 1323-1339.

17. Pins MR, Young RH, Daly WJ. Primary squamous cell carcinoma of ovary: report of 37 cases. Am J Surg Pathol 1996; 20: 823-833.

18. Sakuma M, Otsuki T, Yoshinaga K, et al. Malignant transformation arising from mature cystic teratoma of the ovary a retrospective study of 20 cases. Int J Gynecol Cancer 2010; 20: 766-771.

19. Araujo IB, Pinheiro MV, Zanvettor PH, et al. High Frequency of Malignant Transformation of Ovarian Mature Teratoma into Squamous Cell Carcinoma in Young Patients in Northeast Brazil. Int J Gynecol Pathol 2016; 35: 176-184.

20. Oranratanaphan S, Khemapech N. Characteristics and treatment outcomes of patients with malignant transformation arising from mature cystic teratoma of the ovary: experience at a single institution. Asian Pac J Cancer Prev 2013; 14: 4693-4697.

21. An JS, Wu LY, Li XG, et al. Clinical analysis of 44 cases with malignant transformation of ovarian mature cystic teratoma. Zhonghua Fu Chan Ke Za Zhi 2013; 48: 123-128.

22. Futagami M, Yokoyama Y, Mizukami H, et al. Can malignant transformation in mature cystic teratoma be preoperatively predicted? Eur J Gynaecol Oncol 2012; 33: 662-665.

23. Black JD, Roque DM, Pasternak MC, et al. A series of malignant ovarian cancers arising from within a mature cystic teratoma: a single institution experience. Int J Gynecol Cancer 2015; 25: 792-797. 